\title{
Creating Identity: The Online Worlds of Two English Language Learners
}

\author{
ANNE BURKE \\ Memorial University
}

\begin{abstract}
The online activities of new English language learners can reveal rich and varied literary behaviors, which are almost invisible in the middle grade classroom. While these nonnative English speakers may experience cultural and linguistic apartness and struggle to express their identities at school, many develop online identities using their literacy skills in a highly productive, engaged, and anonymous fashion. When viewed through a New Literacies (Gee, 2000; Street, 1995) and Multiliteracies (Cope \& Kalantzis, 2000) perspective, closer analysis of the predispositions, social attitudes, and activities of these students reveals significant educational advantages that may go largely undetected by educators in the traditional classroom. This article presents a qualitative case study, involving two English language learners, who actively sought out and engaged in online spaces where they could establish identities, practice multimodal literacies, and seek out affinity groups in keeping with their personal interests and abilities. This research is of significance to educators as it demonstrates the manner in which digital technologies can provide equitable access to literate practices for English Language Learners in the classroom.
\end{abstract}

\section{Introduction}

Less than a generation ago, students' text-making in school was very similar to that of their parents or grandparents. Invariably, it involved handwriting or printing on paper, skills familiar to anyone who had passed through a classroom. Today, however, through the availability of computers, smart-phones, and tablets, technology has expanded into students' lives in ways their parents could hardly have imagined. This paper demonstrates how two English language learners, Lourdes and Aamir, negotiate powerful discourses in virtual spaces to establish identities. These youths utilize multimodal literacies found in social networking and gaming sites, in particular, to build upon cultural capital consolidated through online interactions. Youth participate in discourse communities built around online experiences, developing virtual identities within web-based media, designing texts online, and using and remaking other forms of representational and communicational texts.

These new texts involve communication methods that require sophisticated multimedia skills (Andes \& Claggett, 2011; Kist, 2007; McGinnis, 2007; Mills, 2010; Rowsell $\&$ Burke, 2009). Understandably, current and developing research in the field of multimedia and literacy addresses these new texts. Both Andes and Claggett (2011) and Kist (2007) challenge educators to incorporate new literacies practices in the classroom as an alternative means to facilitate the development of reading and writing skills among students. In a similar way, McGinnis (2007) focuses on the use of inquiry-based projects for his study of student literacy and language development in relation to their social world. This was emphasized by McGinnis in his work among the children of migratory 
agricultural workers. In this study, students explored the meanings of country, home, and loss in their textual production. It is important, however, to consider the digital literacy proficiencies of students in these sorts of studies. Mills (2010) is thorough in her reexamination of current research in the field of multiliteracies and presents several important arguments surrounding multimodal practices and digital communication. Notably, Mills (2010) contends that educators cannot assume all students are digital natives, or native to the use of digital technologies. In order to engage students in the practice of multiliteracies, educators must go beyond the adoption of the traditional curriculum and work to expand students' digital skills. Although students develop many multiliteracies practices without formal instruction, Mills asserts that emphasis must be placed on digital scaffolding when instructing students in these practices in the classroom. Rowsell and Burke (2009) importantly situate this sort of digital scaffolding practice in the contemporary Canadian classroom. Specifically, their research engages very closely with digital reading practices. They discuss digital reading practices through a multimodal framework and the manner in which these differ from traditional schoolbased literacy practices involving print. They show that digital texts created by students are often associated with personal constructed identities (Alvermann \& Heron, 2001), and aspects of this text-making can be seen in blogs, 'wikis,' web pages, instant messaging, and social media platforms. In her more recent work, Alvermann (2008) expands her focus from the examination of online content created by students, to the inclusion of students in discussing the manner in which these online literacies (i.e. identity construction) can be incorporated in the school classroom.

To further understand identity construction, in the online literacies of youth, it must be considered how these identities are intertwined with big ' $D$ ' discourses, defined by Gee as "the enactment and recognition of socially situated identities or 'kinds of people"" (Gee, 2009, p. 9). For English-language learners, this means there is often a disconnect between their school-based identities, their discourses at home, and the identities and discourses they experience in their online worlds. And, as Gee submits, school is often a "place where a focus solely on language is inadequate" (Gee, 2009, p. 16). It is only by exploring online interactions that we can more fully understand identity construction, as a student's use of and interactions with technology, "provide(s) virtual spaces for experimentation with language, as well as with identity, and where there is a purposeful manipulation and projection" (Rowsell \& Abrams, 2011 p. 1). Thus, we are able to situate online identity construction in terms of recent theoretical accounts, away from the idea of identity as a stable entity and toward a current understanding of identity as a dynamic practice.

Students' textual engagements outside of school often differ significantly from their engagements with the traditional texts typically used in standard school curricula (Burke \& Hammett, 2009). My own research in this area, amongst elementary and middle school children, consistently reveal interesting differences between how teachers and researchers assume students are using technology and what they are actually doing outside of school (Burke \& Hammett, 2009). In a recent study, Sanford and Madill (2007) examined the gaming practices of adolescent males in an attempt to determine what types of literacy skills and understandings are obtained through interaction with alternative learning practices. Emphasis was placed on video game play as a learning practice that occupied a significant amount of out-of-school time for these male students. Observation led 
researchers to conclude that these boys were exposed to both significant and powerful learning through their engagement with video game play. Furthermore, this study questioned assumptions about in-school learning and seemed to underscore the potential for out-of-school learning through new literacies practices. Interestingly, the English language learners I have encountered through research have revealed online literate lives, which are almost invisible in the classroom. Using the anonymous gateways afforded by the Internet, new English language learners can acquire and practice literacy skills in a highly productive fashion, often flourishing more online, without classroom peer pressure and the academic scrutiny of teachers. This online activity, which can be of enormous personal and educational value and impact, is frequently overlooked by education systems. Teachers may be overlooking an opportunity to engage English language learners unwittingly, or they may not realize their students' grasp of English literacy exceeds that which has been demonstrated or evaluated in the classroom. Closer scrutiny of new English learners' online activities through a multiliteracies perspective (Cope \& Kalantzis 2000) can point a way forward to new and valuable teaching. In the section that follows, I will look at multiliteracies research that can further expand our sociocultural and discursive understandings of literacy, especially as they are related to English language learners.

\section{Literature Review}

\section{Expanding our Notions of Literacy}

Sociocultural theories about literacy, such as those of New Literacy Studies (NLS), (Gee, 1996; Street, 1993; 1998) present literacy as more than a set of decontextualized skills, acquired through transmission forms of teaching. Rather, the NLS regards literacy as a set of social practices, which are influenced by the social and cultural contexts in which they take place. Students, therefore, use literacy to for social purposes across the literate spaces of their lives. NLS carries an understanding that literacy is ideological and that literacy practices are both situated within the context of a community and interwoven with the values and beliefs of that community.

Underscoring this ideological understanding of literacy as primarily social and fundamentally dynamic is the idea that literate social practices consist of discourses (Gee, 1996; 2001). Discourses are described as "socially recognized ways of using language (reading writing, speaking, listening) gestures and other semiotics (images, sounds, graphics, signs, codes), as well as ways of thinking" (Lankshear \& Knobel, 2007, p. 3). Gee (1999) explains the acquisition of discourses come from two areas of one's life: "primary discourses" are the ways in which one is socialized in early life, through the literacies engaged through one's family and community "secondary discourses" are learned through institutions of schooling and religion. These learned "ways of being" grow with a person's literate ability to use different discourses or "tool kits" to communicate and engage multiple discourses. Gee elucidates how school systems have the tendency to value secondary discourses, which align with school and other institutions of power, over a student's primary discourses from home and community. For our purposes, these primary discourses related to online literacy practices may also importantly include their connection to an online community, in addition to the home and community of their real world, lived experience. 
In the study chronicled in this article, the English language learners were highly engaged in out-of-school activities, which were of great importance to themselves, yet almost entirely outside the scope of their in-school activities, the site of their secondary discourses. This is an important consideration for our engagement with Bourdieu and the implications for the manner in which one's cultural background may inform the sort of cultural capital available to a respective individual.

Bourdieu's reflective sociology studies $(1984,1990)$ are relevant to English language learners because they look specifically at how society's social relations, structures, and agency relations, determine an individual's actions and ways of existence. An individual's habitus (commonly defined as the dispositions of social groups acquired through the experiences of everyday life) is created through dispositions, which are acquisitioned through socialized norms within society. Importantly, the habitus, which reflects one's cultural background, determines one's cultural capital within society. Accumulation of particular types of capital can determine the range of choices an individual can make. Bourdieu (1990) also suggests that social or cultural capital can be accumulated and converted from more symbolic forms to more powerful material and economic forms.

This paper demonstrates how two English language learners augmented powerful discourses in virtual spaces to establish identities they themselves desired. Through multimodal literacies found in social networking and gaming sites, in particular, these youths build upon cultural capital which was pre-disposed in both youths' habitus and consolidated this equity through online interactions.

\section{Framing Literate Space and Language}

The English language learners in this study framed online spaces to achieve particular political and cultural purposes. The use of digital language forms found outside the classroom engaged their communicative practices and were used to achieve agency, for example, the specific ownership of their own multimodal choices when engaging in online and within community practices. Multiliteracies theory recognizes the numerous ways in which meaning can be made through reading and writing, text print, digital and multimodal texts, and it expands the term 'text' to include cultural and contextualized practices with multiple modes of text representations (New London Group 1996; Cope \& Kalantzis, 2000; Jewitt, 2008; Kress 2003). Kress (2006) suggests that with the screen taking dominance over print media, there is a need for students to become familiar with, and use, the meta-languages of digital texts. Kress (2006) argues that writing no longer holds a dominant role within the modes of communication:

But the modes of representation and media of communication are different: image has taken many of the functions of writing . . . the web [has become] the dominant site for getting information as the raw material for knowledge; and in any case authorities are treated with scant regard. (p. 2)

Multiliteracies theorists recognize the vastness in multiple communications channels, new hybrids in text creations, and the prevalence of linguistic and cultural diversity. According to the New London Group (1996), "Multiliteracies also create a 
different kind of pedagogy, one in which language and other forms of meaning are dynamic representational resources, constantly being remade by their users as they work to achieve various cultural purposes" (p. 64). Using multiliteracies theory to view students' literacy practices invites opportunities for further inquiry into youth engagement of electronic texts amid changing school populations. Alvermann (2008) cites a study conducted by Guzzetti, where literacy is understood as a social practice to frame the negotiation of electronic texts by her two subjects of study. In this case, presenting student literacies as socially situated practices, as with my subjects Aamir and Lourdes (all names are pseudonyms), participants showed how they embraced linguistic and culturally diverse ways of using language in virtual spaces, and how these virtual spaces became spaces of learning, spaces where social and cultural development occurred. Considine, Horton, \& Moorman (2009) contend that, "The challenge for teachers is to connect the literacy skills that students develop in their social environment with the literacy environment of the school" (p. 486).

Multiliteracies pedagogy requires educators to respond to new technologies and communication practices within an increasingly culturally and linguistically diverse society. These goals are designed to help students participate fully in all aspects of their lives, including their work, civic, and private lives. This goal has particular resonance for English language learners such as Aamir and Lourdes, who use online activities in a particular fashion to further their upward mobility discourses and bridge the gap between their school and home lives.

\section{Methodology}

Case study research may be considered particularistic in that it focuses on a particular situation, event, or phenomenon (Stake, 1995). This particular research took place in a province in Atlantic Canada where tight government funding has forced the amalgamation of smaller schools and school boards. The urban school population has become quite linguistically and socio-economically diverse, as a result of a large rural inmigration combined with an influx of international immigrants to the province's capital. These social, cultural, and economic challenges are all factors in the area's struggling literacy rates. As a 'bounded case' (Stake, 1995), the study looks specifically to the students' literate lives and shows how young learners harness literacy through reading and writing online in the worlds in which they live.

Merriam (1998) describes case study as an 'intensive, 'holistic' description and analysis of a single instance, phenomenon, or social unit" (p. 21). This systematic case study illuminates participants' literacy engagements online, specifically: how they use the internet to create identity, their own understandings of the implications of such practices, and how their critical use of texts may address other issues such as friendship and the augmentation of home literacy practices. Qualitative data is considered powerful because it is sensitive to the social, historical, and temporal contexts in which it is collected (Patton, 1990). Contextual understanding of the literacy practices of these young adolescents resulted through the data collection of literacy logs. The participants were asked to fill out a log, based on their literate engagements, about the types of digital and print texts they use in their out-of-school computer engagements. In designing the literacy $\operatorname{logs}$, I made an effort to include the types of multimodal texts and leisure activities which students of this age group were engaged. These ranged from visual art 
to dance classes, music lessons, to writing on a blog. Essentially, I asked children the following questions:

1. 1 Do you write or draw in your spare time at home? This can be on the computer (ICT, e-mail, web page design, downloading of music etc) or in a hand written diary, draw in a portfolio, scrap book design, and photography.

2. List what you read at home (textbooks as well as other texts such as newspapers, magazines, web pages you design or visit, Cd covers, e-mails etc.

3. List the activities that you engage in after school. This may include music, drama, dance, art, sports, using a computer at home for e-mail, web page design, ICT. Video games on your own or with friends.

Please record these in the exercise book provided.

Literacy Practices (Point form)

\begin{tabular}{|l|l|l|l|}
\hline Days of the Week & Before Class & After School & Evenings \\
\hline Monday & & & \\
\hline Tuesday & & & \\
\hline Wednesday & & & \\
\hline Thursday & & & \\
\hline Friday & & & \\
\hline Saturday & & & \\
\hline Sunday & & \\
\hline
\end{tabular}

Data strands were created based on the literacy log responses to find out:(1) the types of multimodal texts being used, (2) when the multimodal texts are used and the virtual spaces with which the subjects engaged, and (3) whether the multimodal texts are collaborative or individual in nature. The collection of this data in this way yielded a rich data set that provided direction for the interviewer to ask about recorded literacy practices during the individual interviews.

The particular middle school chosen for this study had a diverse population of students from multi-ethnic backgrounds, representing the current demographic changes in city centres within the province. Although the school population hovered around 500 students, almost 20\% were English language learners engaged in English as a Second Language (ESL) studies. The classroom where I performed most of my research consisted of 19 males and 11 females. Six students in the classroom were English language learners; three attended regular ESL instruction classes for one formal period a day and were offered extra instruction as needed. The classroom teacher, Chantelle ( $a$ pseudonym), taught language arts to this group of students for an hour every day. To find out more about online practices, students were interviewed two times at their middle school while they engaged in computer activities. I also discussed with each student his/her completed literacy log. As this study also encompassed the home literacy practices of the adolescents, parents of all the participants were asked to share their 
perspectives on literacy. Two of the eight students in the case study were newcomers to both the province and Canada. Both were conscious of their newcomer status and occasionally struggled with forming and adapting to their new identities. It is their experiences on which this article is based and the following sections provide biographic detail of these participants to contextualize the study findings.

\section{Lourdes}

Thirteen-year old Lourdes is from Colombia and her first language is Spanish. Spanish is spoken at home although Lourdes, her father, and her brother are competent speakers and writers of English. Her mother, however, is still in the process of learning to speak and write English proficiently. Lourdes was an avid reader of fantasy, science fiction, novels, and computer sites. She used the computer for visiting websites of interest for players and participants: video games, discussion forum chats, MSN and e-mail. She also used the computer to pursue her love of computer generated art programs like Paint and other Adobe creative programs.

Lourdes's home and out-of-school practices included: MSN (instant messaging) popular with her friends still in Columbia, forums and chat-rooms, games, journals, and e-mail. Many of these practices showed how she constructed her identity through these digital texts. Her fascination with dream catchers (home-made artifacts based on Indigenous culture, which are designed to capture negative dreams), MSN, e-mail and online forum discussions paralleled her reading preference for science fiction and fantasy genres. Within her home and cultural practices, Lourdes engaged in debates about religion with her parents. She was also an active participant in online communities such as www.BlueKaffee.com, a local website that hosts forums and chat-rooms on many subjects. She used this site to post her writings and journals and saw it as an expression of who she is as a person. She used an avatar as a pseudonym and more so as a way of keeping her diary and journals anonymous and private. Observations of Lourdes in the classroom setting and in our interviews, show Lourdes to be a very competent learner, who was doing well in school, considering English is not her first language. She was adept at self-instruction and enjoyed experimenting with many of the literacies in her life, often through domains of practice that exist outside of schooling environments.

\section{Aamir}

Aamir engages in literacy practices stemming from his avid reading in the genres of traditional literature and fantasy and from a fascination with the Pokémon world. Aged 13 during the study, Aamir emigrated from Pakistan to Canada at the age of eight. He had been in the province for three years, after an earlier sojourn in Saskatchewan. This move had not been easy for him, and he admitted that he had sometimes struggled with the social challenges of establishing new friendships and social networks for the second time in such a short period. He was the youngest in his family, and had older siblings attending university. Aamir was an above average student who received "B" grades and was often challenged by the classroom teacher to develop his classroom writing beyond literal responses. He liked to complete his schoolwork on the computer and enjoyed video games, Japanese Manga, and role-playing games like Dungeon and Dragons. Aamir used technology to maintain relationships with friends and family back in Pakistan, generally through e-mail and MSN (instant messaging). He was a competent technology user who saw how using the Internet could collapse time and space, enabling him to maintain relationships with others. He extended his love of reading to drawing anime (Japanese 
animated art) in his spare time, a literacy practice he shared with an older sister who taught him how to draw.

Aamir saw himself as a "gamer" and looked for online communities to extend his playing. He read and posted his thoughts and advice about playing games on www.gamespot.com and on related discussion boards. Coupled with this exuberance for the game, was Aamir's socially constructed understanding of the discourses associated with the gaming world, an understanding that materialized in our interviews. This sort of research methodology has allowed for us to give voice to the multiliteracies practices of these two English language learners, as well as socially situate them in terms of their cultural and linguistic background. It is important to note, however, that this methodology is not without its limitations. For example, this study was a purposeful sample of eight students. The children came from supportive homes with well educated and engaged parents. We can only assume the literacy logs were reflective of both participants' literacy engagements, although we did make an effort to have parents confirm his/her child's practice through the parent interviews. This next section shares the research findings gathered from the case studies of Lourdes and Aamir.

\section{Findings}

\section{The Virtual Lunchroom}

Both Aamir and Lourdes participated in forum posting or chat lines. Unlike the other research participants who were satisfied to read postings, both adolescents sought online communities where they could share and discuss their interests in more depth. These actions also spoke to the affordances offered through online engagements to maintain relationships or to find a new community of learners. Unlike the classroom and break periods at lunch and recess, where both ESL students are explicitly aware of their linguistic differences, online environments afford a space of equity for English language learners such as Lourdes and Aamir. Both students made use of powerful literacies to advance their understanding of socially situated literacies common in adolescent practices, such as chat lines and gaming. One such socially situated practice would be looking at Japanease Anime and practice drawing such as the figure drawn by Aamir. 


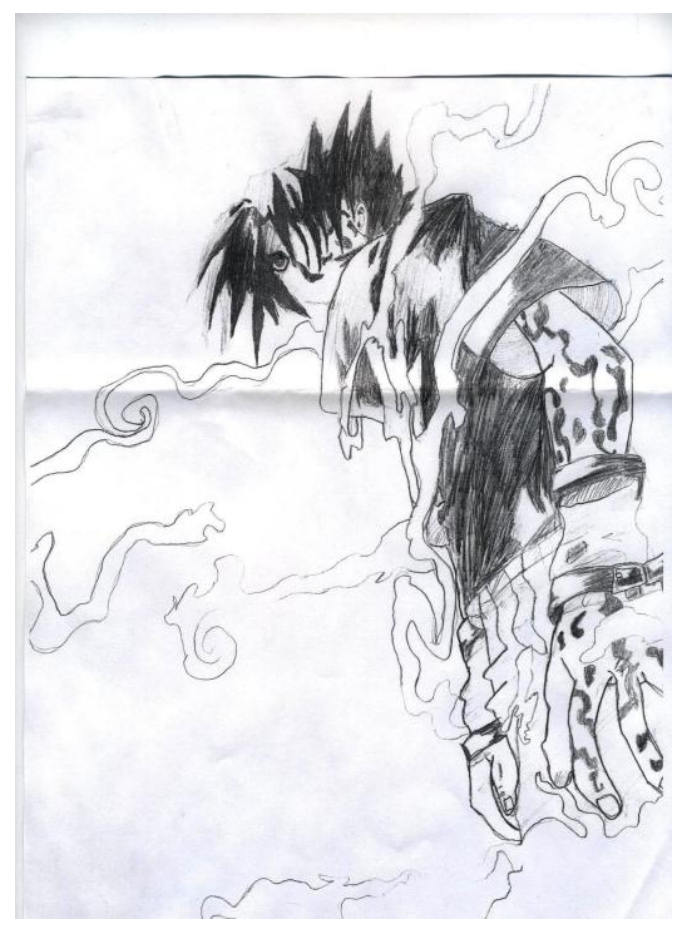

Figure 1: Anime character inspired from reading and watching Manga style cartoons

As Thorne, Black, \& Sykes (2009, p. 21) discovered, "Fan communities centered on Japanese media, such as anime (animation) and manga (comics), provide compelling examples of the hybrid and participatory nature of the language and literacy practices taking place in online interest groups" As a testament to the compelling nature of these participatory groups, students in this study would also make use of computer time in the library during their school breaks to visit these online spaces.

Lourdes was very engaged with the local online community www.bluekafee.com. Her online forum engagements and postings in chat-rooms demonstrated how she extended home literacy practices valued by her family, such as debating, to the wider online world. Lourdes explained her desire to seek out debating opportunities and to discover how others think, revealing her desire to discover and connect with affinity groups:

Well I read a lot of forums [debates] on bluekaffee.com and on websites that interest me, or calls on my attention, and when I have an opinion about the debate that is on the forum [laughs] of course I am going to give my idea to everyone else. And, for that you have to choose very specific words so that the rest of the people understand you with no errors.

Her comment about "no errors" shows Lourdes's understanding of her own identity; within the context of the bluekafee.com community, her writing needed to be very clear if her point was to be valued by other participants. Lourdes shaped her writing to engage in her family literacy practice of debating while at the same time positioning herself as an author, where her readership in a global community needed to "understand [her] with no errors". To become part of this discourse community, she recognized that her challenge, as a school identified ESL student, was to assume the identity of a writer whose 
communication needed to mimic the other writing she encountered on www.bluekafee.com. This mimicry was largely as a result of having been visibly labeled as an English Language Learner, and her desire to gain access to these discourse communities.

Lourdes's engagement with this online community was built upon the support system that she had from her family and home and seemed to have little to do with her classroom writing. Her family already valued the important literacies and social capital which could be gained through online interactions. Even though, as new immigrants, they were not empowered by the local culture, from a Bourdieuian perspective (1990) the family's comfort with computers and intellectual conversation demonstrates that they nevertheless enjoyed an empowered social position. Pre-disposed through family discourses, which provided this type of social access, the families' local literacy practices offered a repository of knowledge that Lourdes could draw upon to bring greater meaning and understanding to her own world. Through online posting with bluekaffee.com, Lourdes found a discourse community in which she could read about the life experiences of others and share her own. One posting, which she forwarded to me by e-mail, illustrates the emotional texts teenagers write in private.

There's somethings in this world that just don't change but then there are those things you want to change but you can't for some nonsense reason

As far as my life goes there is a million things that I could talk about, but there is only one thing I'm afraid to remember and that is when I meet "you."

Today was one of those days that makes you laugh and cry inside, the pain is never gonna go away until I face my fair, "you."

I just don't want to face it, not yet. But when I do I hope we are gonna be and I hope to be the best person you have ever met or at least one of then and if not...

then just let God disside.* (by Lourdes)

When asked about the use of an asterisk for the closing word, 'disside' (sic), she explained it was used to indicate she was unsure of the spelling. This action showed not only her understanding of the importance of mechanics in writing, but also her trust in this online community. Lourdes enjoyed posting anonymously and belonging to a private space where she was able to write and post how she felt without being judged by her appearance or accent. The subtext of this belief was its corollary: that she could not offer her thoughts and opinions in the classroom, either because there was no opportunity or because of hesitation rooted in her linguistic and cultural differences.

Because of Aamir's relationship with his sister, and their shared interest in the art of Anime, he became a part of the community of www.narutofan.com. Aamir was a great fan of the Japanese anime series Naruto. Naruto is a fantasy world, which takes elements used in role-playing games, such as Dungeons and Dragons, and fuses them with Samurai 
history, Japanese pop culture, and martial arts movies. Aamir considered himself well versed in the nuances of the stories and characters; he spent considerable time drawing his own versions of the comics, reading and posting about them on fan sites, and watching episodes subtitled online in their original Japanese.

When asked about a video discussion forum on Narutofan.com, Aamir said, with some hesitation, "I do post once in a while if I find a topic that interests me. My sister usually just reads." His comment of posting "once in a while" suggests that he was just learning the discourses of narutofan.com and was starting to augment this home literacy practice to a local literacy, one within the affinity group. It is also important for us to consider the sorts of literate practices that must be demonstrated by individuals as members of these affinity groups.

\section{Avatars: Extending Identity}

Lourdes felt avatars, online graphic representations of one's persona, should be private, and the selection of one should be tied to personal and symbolic representation. Her choices for an avatar were closely associated with the philosophies she held of life. Although she admitted to using avatars with Columbian pals on MSN, she also discussed how in her online postings for www.bluekafee.com, the use of an avatar was private and something she wished to conceal: "My avatar always has meaning to me but not always to others." In our conversation, she revealed that the creation and maintenance of an avatar for privacy coincided with her desire to find a secure space for her on-line diary. This critical framing of literate practice demonstrates how she rethinks the purpose and form of her on-line writing for an audience. The traditional print forms of diaries risk public exposure, whereas the affordances offered through the engagements on www.bluekaffee.com offer the creative anonymity she so desperately seeks.

I like writing my thoughts but not diary writing. I figured out that diaries are not always kept secret, or poetry... I just write what goes on in my head, and sometimes it is difficult because a lot of things I want to write come quick... I do my best, and sometimes they do end off rhyming.

Similar to Lourdes, Aamir felt that he needed the cloak of avatars and anonymity in order to share his true thoughts: "I always post with a different name. Nobody knows who I am." When asked about the anonymity of the interaction, he commented, "I kind of do [like it] because it gives me a chance to be whoever I want to be, unlike real life." He also admitted to using a moniker instead of his real name to once again ensure the anonymity that allowed him to avoid the embarrassment associated with possible language expression errors: "I feel more confident because nobody knows who I am, and I don't feel as shy or embarrassed." For both students, the use of avatars and monikers empowered their out-of-school identities, and exercising the ability to conceal or protect their identities online also helped to mitigate their language skill limitations and sense of otherness.

\section{Discourses and Identity}

Gee describes primary discourse as that which establishes our sense of self, the one that "sets the foundation of our cultural specific vernacular language" (Gee, 2009, p. 11). Secondary discourses are identities often acquired elsewhere, like schools. For 
English language learners like Lourdes and Aamir, their primary and secondary discourses interacted in a complex fashion.

I observed Lourdes in the classroom enacting a number of primary and secondary discourses, often tied to her ESL status. She tutored and helped other Spanish-speaking students, as she believed that it was her responsibility to help her peers from her homeland. This action was also part of her constructed identity as a teacher and translator, and it drew on powerful pre-disposed discourses held by her parents that top school marks lead to post-secondary school and upward mobility. Lourdes positioned herself to empower her own learning as well as that of other English language learners in the classroom. Her comments suggest that success in her life would have to be through good grades and language with "no errors," echoing the secondary discourses, which guided her language arts classroom. Her new identity was implicitly encouraged by the classroom's limitations. While the classroom teacher tried to accommodate the learning needs of English language learners, she also felt that second language instruction was primarily the responsibility of the ESL teacher, who was only present sporadically. The teacher referred directly to Lourdes's useful in-class tutoring of another Spanish student, stating, "He gets some help when I cannot provide it." She would often have language arts worksheets provided each day to keep identified ESL students on task. The teacher's comment, which suggests frustration with a system lacking in support, shows how English language learners can be marginalized when multilingual diversity is not addressed through adequate ESL instruction time or professional development and TESOL training for teachers. Educators and administrators likewise need to recognize the importance of English language learners' linguistic and cultural knowledge as valuable contributions to learning within the school contexts (Cummins 2001; 2004).

When asked about his interactions with peers in class, compared to his experiences online, Aamir suggested that his social capital was more apparent in virtual spaces than in class. As the son of a professor, it was made clear to him that good marks were a very important part of the path to success and entry into university in Canada. Importantly, it must be pointed out that Aamir was predisposed to understand the value of school and how a solid education would enhance his social position and that of his family.

He engaged in a number of identities in school that depended on the social situation, the peer group with which he was interacting, and the activity in which he is participating. Aamir was fully aware of the cultural and economic discourses needed to negotiate the discursive repertoires needed when interacting with the diverse socioeconomic contexts in which he interacted, whether they were home and community based, through religious practice, online, or in school. This was notable in school, for example, in his great love for sports and tracking scores on the Internet. Often his entry into classroom discussions was animated by sports play talk focused on the latest NBA scores. He had mastered various online sports sites in order to have this information readily at hand. This identity, which characterized his everyday literacy practices at home, empowered him to find common ground with school friends. Conversely, he shared that he did not see his school friends on the weekends, because he spent most of his time with his family or at the Mosque. Although there were others in his school from his Muslim community, he generally avoided them at school, preferring to create his own identity as a sports fan, free of the primary discourse of his home life. His deep understanding of the various discourses at work in his life gave him the ability to move 
consciously among these identities as the social situation and requirements around him changed.

\section{Identity and Cultural Capital}

The activities of Lourdes and Aamir show how they constructed identities through the texts of their lives, positioning themselves for greater access to social capital and status within their schools and with friends. Lourdes's search for more powerful discourses such as an author is part of the powerful home culture practices from which her habitus was formed. In an interview, Lourdes's father suggests how elite discourses are upheld and ascribed to in the home: "We believe our children have gained not only deep but broad knowledge about the surrounding world through reading, and listening to stories, and seeing themselves how that applies to the real world." His mention of reading the texts in one's life evokes Freire's philosophy of learning within the world, "learning by doing." Lourdes's cultural literacy practices and predisposed interest in debating is empowered through her use of digital technologies, such as on-line chat forums. She uses these forums to gain social capital valued in her primary discourses, and also to enhance the social disposition as an author and thinker, which is part of her habitus.

Aamir, unlike many of his classmates interviewed during the larger study, cherished the time he spent with his family. He shared that his brother encouraged his online gaming, and his sister nurtured his interest in Anime. He was a huge fan of Manga films and videos, an enthusiasm that extended to online forums. As was the case with Lourdes, even though his parents were not always comfortable with the local community's attitudes, they were well aware that Aamir's online activities had value that went unrecognized in the classroom. In an interview, Aamir's father expressed concerns that evaluation of grades was the sole focus of schools. He wished he had more opportunities to meet his son's teachers and that their exchanges would be more lateral, "I think it will be nice if parents and teachers communicate more often than just having one parent teacher meeting at the end of study term."

Both students had an implicit understanding of the discourses surrounding language and how these influenced the social spaces of their lives. Lourdes understood the sociopolitical power of mastering alphabetic texts in her world; she understood that by acquiring powerful dominant discourses other than her own, she could in turn position herself in more powerful discourse communities (Gee, 2001). Although the world of the classroom ESL learner can be perceived as one that struggles to gain mobility through alphabetic texts, particularly when they represent a language difference, the reality is that the primary discourses of one's language and culture (Gee, 2004) may be more complex than they first appear. Lourdes implicitly understood that good grades achieved through particular texts could be equated with later post-secondary opportunities. Williams (2006) says that "standardized testing provides evidence of cultural and class status that maintains the values of academic discourse for the dominant culture either attesting to the worthiness of those already in the system or acting as a gate for those outside it" (p. 344). As a newcomer, the power associated with the attainment of particular literacies was highly valued in Lourdes's home and amongst the Colombian community. As an English language learner, her comments about the sociopolitical power of alphabetic texts, as opposed to the other texts that composed her literate life, demonstrated a worldly awareness of the valuing of the linguistic mode in official school literacies (Hull \& 
Shultz, 2001). This understanding of social and cultural perspectives of literacy relates how language and power are intertwined in her life. Lourdes's ability to harness literacy, using her newcomer's understanding of the value of dominant discourses, illustrates how literacy can be a mobilizing tool for social positioning, thus attesting to the social, cultural, political, and economical capital associated with it (Gee, 2000).

Lourdes found an affinity group at bluekaffee.com, which shared similar discourses, discourses she could not access elsewhere in her life. Aamir's admitted to visiting fan fiction sites, but not posting to the sites, suggesting how texts can be used by groups to negotiate degrees of access. Whereas Lourdes was an active participant in her affinity group, Aamir instead chose to learn through observation. Both would seem to indicate that a command of the English language is requisite for understanding how one is to participate on a respective online site. (Barton \& Hamilton, 1998). The students' changed notions of texts suggest an implicit understanding of how language use can be political, positioning them in differing places within their social worlds. These examples of students' interactions with these texts show how texts ascribe identity, ideology, and power. Through their literacy practices, students illustrated the embedded nature of literacy, expanding beyond language-use to an understanding of how language may be used to achieve multiple purposes across varying contexts (Barton \& Hamilton, 1998; Cope \& Kalantzis, 2000; Kress, 2003; Luke \& Freebody, 1999; New London Group, 1996; Street, 1993).

\section{Bridging School and Home Together}

As their teacher, Chantelle attempted to situate ESL student learning with reference to their own learning and local literacy practices. This was often a struggle for her, as she had little or no information with which to contextualize her newcomer students' knowledge. The tools Chantelle did have, such as vocabulary sheets and other handouts such as guided comphrehension activities, were not particularly useful because they are often considered tools to simply "occupy children" rather than engage them in meaningful language learning informed by cultural and social context. As a result, language learning processes, were often heavily compromised by the classroom practices and discourses. This observation suggests that a more balanced teaching approach, using the ESL student's cultural knowledges, would have made this school task more engaging and meaningful. As Delpit (2006) argues, "Students need skills to open the doors, but they need to think critically and creatively to participate in meaningful and potentially liberating work inside those doors" (p. 20). Based on my observations of the literacy practices of students, such as Lourdes and Aamir, many of their out-of-school literacy practices and online engagements harnessed online tools to construct multiple identities which gained access to multiple discourse communities (Street, 1993; Gee, 1996). This relates how their literacy practices are more than just skills-oriented and demonstrates the embedded social nature of their engagements (Street, 1995).

\section{Discussion and Conclusion}

Researchers like the New London Group (1996), New Literacy Studies (Gee; 1996; Street 1993), and Multiliteracies proponents (Cope \& Kalantzis, 2000) raise questions about how to teach in a world where computer screens are becoming the dominant form of communication (Kress, 2003). Early observations of Lourdes's and 
Aamir's online writing and website interactions clearly illustrate that their writing practices were very different from the task writing which dominated the language arts classroom. This difference was particularly visible within the constructed identities that they engaged when writing texts outside of school, such as Lourdes's online poetry writing and Aamir's engagements with virtual gaming worlds. Students' conception of language also seemed to demonstrate an implicit understanding of the importance of the primary discourses of their homes as well as those secondary discourses required by the school and social situations.

Not unlike other places in North America, the advent of technology, rural migration to urban areas, and an influx of international immigrants have introduced a changed school population in this small Canadian province. Teachers like Chantelle attempt, with varying degrees of success, to include ESL learners within their everyday classroom practices. During the course of this study, it became evident that more information about students' multilingual capabilities and cultural backgrounds would have assisted the teacher in connecting the curriculum to their prior learning experiences. Schools and school boards need to make a greater effort to learn about and make visible valued cultural practices that ESL students use in their homes. This could be achieved through increased home and school communication, for example, family literacy nights, where parents are invited to the school to share in celebration of their cultural practices with educators.

Schools also need to use texts as a way to bridge to the rich cultural literacies of the home. It is important to note that Lourdes and Aamir enjoyed a certain privilege given their family's cultural and economic positioning, as well as the emphasis placed on school success at home. However, we cannot allow these considerations to diminish the success of these students. The home literacy logs, which were used in this study to identify valuable literacy practices that characterized the lives of students, could be used in any classroom as springboards to inform and enrich conversations about students' local and cultural practices. This can take place alongside conversations with teachers in order to understand students' out of school engagements. While both of the students represent the emerging cultural and linguistic diversity of all Atlantic provinces, they also share many aspects of their lives with their fellow students in ways that give them power such as social networking, blogging and being apart of affinity groups, while developing identities different from those observed in the classroom. While the teacher tended to view their interactions in the classroom in terms of their linguistic abilities, an attitude that in turn was taken up by the students, in reality their lives were defined by much wider discourses. These included a very confident sense of their own social class and their status as digitally competent users in the wider world of the Internet community, all of which could have added to the teacher's content knowledge and experience tool kit for her students. Alvermann (2002) contends that, "culturally responsive instruction, then, is to call for teaching that takes into account everyday, patterned interfaces between home/community and school literacy practices" (p. 197). The students' writing choices showed how they drew from their local, home, and cultural experiences to design texts which represented new understandings of the world and their constructed identities (Cope \& Kalantzis, 2000; Gee, 1996; Street, 1993; Barton \& Hamilton, 1998). These newly creative forms show renewed interests in text-making on the part of youth and are valid 
examples of how educators can connect to the literate out-of-school lives of those they teach through a multiliteracies epistemology involving text production.

Making visible expansive forms of language, and including these in the classroom, requires the inclusion of multimodal texts in the classroom. The placement of technology in classroom spaces would make access easier but could also change the culture of the computer as an output device and instead engage the multiple layers of identity created by the students in this study. If we, as educators, approached literacy with an understanding that it is essentially about how people live, adolescent literacy practices would be perceived as more than just recreational activities. These socio-cultural situated literacies have enormous value within these students' lives and show sophisticated types of reading, writing, and forms of representation. Furthermore, these students demonstrated an understanding of how to use their authoring and creative experiences on the Internet to address the social, cultural, and political facets of how literacy is characterized in their lives.

The two students discussed in this paper created a range of virtual identities which proved to be as empowering for them as their real life social engagements. In this particular study, both students had access to primary discourses and family class backgrounds, which valued the attainment of higher grades, and the social access and mobility offered through education. For Lourdes, virtual engagements empowered her constructed identity as a budding author as well as her identity as an English language learner in a family that understood how constructed identities might be enhanced through digital technologies. Aamir was able to create space for his creativity and develop relationships that were vital to his sense of self. Although both suffered lack of confidence related to their status as immigrants and English language learners, they also benefited from the use of digital literacies in online gaming, chat rooms, and forum postings. Unfortunately, these engagements were unknown to their teacher. This is the gap we, as educators, need to bridge, the vital tool we need to access. Through an understanding of the primary discourses found in the home lives of English language learners, we can see how digital technologies can provide equitable access and further empowerment of literacies currently framing the secondary discourses of these students in their classrooms. 


\section{References}

Alvermann, D. (2002). Adolescents and literacies in a digital world. New York, NY: Peter Lang Publishers.

Alvermann, D. E. (2008). Why bother theorizing adolescents' online literacies for classroom practice and research?. Journal of Adolescent \& Adult Literacy, 52(1), 8-19.

Alvermann, D. E. (2002). Effective literacy instruction for adolescents. Journal of Literacy Research, 34(2), 189-208.

Alvermann, D. E, \& Heron, A. H. (2001). Literacy identity work: Playing to learn with popular media. Journal of Adolescent and Adult Literacy, 45, 118-122.

Andes, L. \& Claggett, E. (2011). Wiki writers: Students and teachers making connections across communities. The Reading Teacher, 64(5), 345-350.

Barton, D., \& Hamilton, M. (1998). Local literacies: Reading and writing in one community. London, UK: Routledge.

Bourdieu, P. (1990). In other words: Essays towards reflexive sociology. Stanford, CA: Stanford University Press.

Bourdieu, P. (1984). Distinction: A social critique of the judgment of taste. London, UK: Routledge.

Burke, A., \& Hammett, R. (2009). Assessing New Literacies: Perspectives from the Classroom. New York, NY: Peter Lang.

Cope, B., \& Kalantziz, M. (2000) (Eds). Multiliteracies: Literacy learning and the design of social futures. London, UK: Routledge.

Considine, D., Horton, J., \& Moorman, G. (2009). Teaching and reading the millenial generation through media literacy. Journal of Adolescent \& Adult Literacy, 52(6), 471-481.

Cummins, J. (2004). Multiliteracies pedagogy and the role of identity texts. In K. Leithwood, P. McAdie, N. Bascia, \& A. Rodigue (Eds), Teaching for deep understanding: Towards the Ontario curriculum we need (pp. 68-74). Toronto, Ontario: OISE, University of Toronto and the Elementary Teachers Federation of Ontario.

Cummins, J. (2001). Negotiating identities: Education for empowerment in a diverse society (2nd ed.). Los Angeles, CA: California Association for Bilingual Education.

Delpit, L. (2006). Other people's children: Cultural conflict in the classroom. New York, NY: The new press.

Friere, P., \& Macedo, D. (1987). Literacy: Reading the word and the world. South Hadley: MA Bergin and Garvey Publishers.

Gee, J.P. (2009). Language and discourses: Meaning is in the game. Retrieved from http://www.jamespaulgee.com/sites/default/files/pub/Language\%20and\%20Disco urses.pdf.

Gee, J. P. (2004). Situated language and learning: A critique of traditional schooling. New York, NY: Routledge.

Gee, J. P. (2001). Literacy, discourse, and linguistics: Introduction and what is literacy? 
In E. Cushman, E. R. Kintgen, B. Krell, \& M. Rose (Eds.), Literacy a critical source book (pp. 525-545). Boston, MA: St. Martin' Press.

Gee, J. P. (2000). New people in new worlds: Networks, the new capitalism and schools. In B. Cope \& M. Kalantzis (Eds.), Multiliteracies (pp. 43-68). London, UK: Routledge.

Gee, J. P. (1999). An introduction to discourse analysis theory and methods. London,UK: Routledge.

Gee, J. P. (1996). Social linguistics and literacies: Ideology in discourses, (2nd ed.). London, UK: Falmer Press.

Hull, G., \& Shultz, K. (2001). Literacy learning and out of school: A review of educational research, 71(4), 575-611.

Jewitt, C. (2008). Multimodality and literacy in school classrooms. Review of Research in Education, 32, 241-267.

Kist, W. (2007). Basement new literacies: Dialogue with a first-year teacher. The English Journal, 97(1), 43-48.

Kress, G. (2006). What is English for? English in Education, 40(1), 1-4.

Kress, G. (2003). Literacy in the new media age. London, UK: Routledge.

Lankshear, C., \& Knobel, M. (2007). New literacies: Everyday practices and classroom learning. New York, NY: Open University Press.

Luke, A., \& Freebody, P. (1999). A map of possible practices: Further notes on the four resources model. Retrieved from www.alea.edu.au/freebody.htm

McGinnis, T. A. (2007). Khmer rap boys, X-Men, Asia's fruits, and Dragonball Z: Creating multilingual and multimodal classroom contexts. Journal of Adolescent \& Adult Literacy, 50(7), 570-579.

Merriam, S. (1998). Qualitative research and case study applications in education (2nd ed.). San Francisco, CA: Jossey Bass.

Mills, K. A. (2010). Shrek meets Vygotsky: Rethinking adolescents' multimodal literacy practices in schools. Journal of Adolescent \& Adult Literacy, 54(1), 35-45.

New London Group. (1996). Pedagogy of multilitercies: Designing social futures. Harvard Educational Review, 66, 69-92.

Patton, M. Q. (1990). Qualitative evaluation methods (2nd ed.). Thousand Oaks, CA: Sage.

Rowsell, J., \& Abrams, S. (N.D.). (Re)conceptualizing I/identity: An introduction. National Society for the Study of Education, 110(1), 1-16.

Rowsell, J., \& Burke, A. (2009). Reading by design: Two case studies of digital reading practices. Journal of Adolescent \& Adult Literacy, 53(2), 106-118.

Sanford, K., \& Madill, L. (2007). Understanding the power of new literacies through video game play and design. Canadian Journal of Education, 30(2), 432-455.

Stake, R. (1995). The art of case study research: Perspectives in practice. Thousand Oaks, CA: Sage.

Street, B. (1995). Social literacies: Critical approaches to literacy in development, ethnography and education. London, UK: Longman.

Street, B. V. (1998). New literacies in theory and practice: What are the implications for language in education? Linguistics and Education, 10(1), 1-24.

Street, B. V. (1993). The new literacy studies: Guest editorial. Journal of Research in 
Reading, 16(2), 81-97.

Thorne, S. L., Black, R. W., \& Sykes, J. M. (2009). Second language use, socialization, and learning in internet interest communities and online gaming. The Modern Language Journal, 93, 802-821.

Williams, B.T. (2006). Home and away: The tensions of community, literacy, and identity. Journal of Adult and Adolescent Literacy,49(4) 342-347

Author Biography

ANNE BURKE is Associate Professor of Literacy Education and Early Learning at Memorial University. She maintains a strong presence in Canadian schools researching new literacies and the role of social media in children's lives. She has authored and coedited a number of books in the areas of children's literate play lives, new literacies studies, and popular culture. Most recently Children's Virtual Playworlds: Culture, Learning and Participation ( co-edited with Jackie Marsh, 2013) Play to Learn (2010) and Assessing New Literacies: Perspectives from the Classroom (co-edited with Hammett, 2009). 